\title{
STRUKTUR KOMUNITAS DAN ZONASI VEGETASI MANGROVE DESA DARUNU KECAMATAN WORI KABUPATEN MINAHASA UTARA
}

\section{(Community structure and zonation of manggrove vegetation at Darunu Village Wori District North Minahasa Regency)}

\author{
Udin Upara, Janny D. Kusen, Calvyn. F. A. Sondak, Joshian N. W. Schaduw, Sandra \\ O. Tilaar, Ridwan Lasabuda \\ Corresponding author : Janny D. Kusen \\ Fakultas Perikanan dan IImu Kelautan Universitas Sam Ratulangi, Manado \\ *e-mail: papakelan@yahoo.com
}

\begin{abstract}
Mangrove ecosystem is a collection of distinctive plant types that contained in tropical and subtropical coastal region. The purpose of research was to find out the community structure and mangrove zonation at Darunu Village, Wori District, North Minahasa Regency. The research was conducted by the quadrant transect line method. It was done by pulling a straight line, perpendicular from the outermost mangrove area to the land direction, along $100 \mathrm{~m}$ by determining three data retrieval Station. To determine the condition of mangrove then density, species frequency, species coverage, important value index, diversity index and equality types were analyzed. The result found 5 mangroves species, namely: Rhizophora apiculata, $R$. mucronata, Sonneratia alba, Bruguiera gymnorrhiza and Avicennia officinalis. The highest density value was R.apiculata, as well as species frequency, while the species coverage value found in S. alba. The diversity value found at Station 2. The zonation of mangrove vegetation in Darunu village respectively, at Station 1 and 2 in the front was overgrown by R.apiculata species with sandy mud substrate. The Station 3 was overgrown by S. alba species with sandy mud. Generalyl, this location substrate contains of sandy mud and mud.
\end{abstract}

Keywords : Mangrove, community structure, zonation.

Ekosistem mangrove merupakan kumpulan jenis-jenis tumbuhan yang khas terdapat di daerah pantai tropis dan subtropis. Tujuan penelitian inilah untuk mengetahui strukur komunitas dan zonasi mangrove di Desa Darunu, Kecamatan Wori, Kabupaten Minahasa Utara. Penelitian dilakukan dengan menggunakan metode garis transek kuadran dilakukan dengan cara menarik garis lurus dari arah laut mangrove terluar sampai kearah darat sepanjang $100 \mathrm{~m}$ dengan menentukan tiga Stasiun pengambilan data. Untuk mengetahui kondisi mangrove maka dilakukan perhitungan kerapatan jenis, frekuensi jenis, tutupan jenis, indeks nilai penting, indeks keanekaragaman dan kemerataan jenis. Hasil penelitian struktur komunitas dan zonasi vegetasi mangrove ditemukan 5 jenis mangrove yaitu: Rhizophora apiculata, Sonneratia alba, Rhizophora mucronata, Bruguiera gymnorrhiza dan Avicennia officinalis. Zonasi vegetasi mangrove di Desa Darunu berturut-turut pada Stasiun 1 dan 2 di bagian depan ditumbuhi oleh jenis R.apiculata dengan substrat lumpur berpasir. Untuk Stasiun 3 di depan ditumbuhi oleh jenis S.alba dengan lumpur berpasir. Secara umum lokasi ini terdapat lumpur berpasir dan lumpur.

Kata Kunci : Mangrove, struktur komunitas, zonasi 


\section{PENDAHULUAN}

Ekosistem mangrove merupakan kumpulan jenis-jenis tumbuhan yang khas terdapat di daerah pantai tropis dan subtropis. Vegetasi mangrove umumnya tumbuh subur di kawasan garis pantai yang selalu diterpa gelombang (Retna dkk., 2016). Komunitas vegetasi mangrove terdapat pada daerah intertidal dan supratidal yang cukup mendapat aliran air dan terlindung dari gelombang besar dan arus pasang surut yang kuat (Bengen, 2003).

Ekosistem mangrove memiliki
struktur komunitas yang khas, menyusun beberapa karateristik secara berurutan seperti pohon, pancang, tiang, semai dan perkecambah sehingga membentuk suatu rangkai zona tertentu. Ada beberapa hal yang mempengaruhi zona jenis-jenis vegetasi mangrove seperti zonasi Avicennia, Rhizophora, Brugueria, dan Nypa menurut Cahyanto dan Kuraesin, (2013) Eksosistem mangrove memiliki struktur yang khas dan mampu beradaptasi dengan lingkungan. Selain itu ekosistim ini berperan sebagai sistem penyangga lingkungan pesisir memiliki fungsi yang sangat besar dalam menjaga stabilitas lingkungan perairan pulau kecil (Schaduw, 2016). Mangrove juga dapat menyiapkan tempat tinggal berbagai spesies dan mampu menyediakan energi untuk berbagai organisme dengan proses fotosintesis.

Menurut Kusen dkk., (2016) dalam hutan mangrove terdapat salah satu spesies tumbuhan dominan yang termasuk dalam 4 famili. Keempat famili tumbuhan atau vegetasi mangrove tersebut dan masing-masing yaitu famili Rhizophoraceae (genera Rhizophora, Bruguiera dan Ceriops), famili Sonneratiaceae (genera Sonneratia), famili Avicenniaceae (genera Avicennia), dan famili Meliaceae (genera Xylocarpus).
Ekosistem mangrove memiliki keragaman spesies yang tinggi, dimana keragaman yang paling besar berada di daerah berlumpur dan terlindung, serta yang berada di dekat sungai besar, sedangkan pada daerah terbuka hanya terdapat beberapa spesies yaitu R.apiculata, S.alba dan A.marina dengan substrat berpasir dan lumpur (Sangari \& Rondo, 1993 dalam Kusen dkk., 2016).

Zonasi pada ekosistem mangrove dari suatu tempat ke tempat lain berbeda tergantung pada kombinasi faktor-faktor yang mempengaruhi (Nybakken, 1992). Selanjutnya Kusen dkk., (2016) menambahkan bahwa tidak semua mangrove tumbuh dengan zonasi yang sama. Zonasi mangrove bervariasi setiap daerah yang berbeda dan tidak ada dua daerah yang sama persis.

Mangrove merupakan beberapa jenis tumbuhan tropis maupun subtropis yang mampu bertahan hidup pada kadar salinitas air yang relatif tinggi dan substrat berlumpur (Sasauw dkk., 2016). Menurut Wantasen (2013), bahwa salintas air dan tanah merupakan faktor penting dalam proses pertumbuhan mangrove tumbuh subur di daerah estuari dengan salinitas 10 30 ppt. Apabila tingginya salinitas akan berdampak pada pertumbuhan mangrove yang dapat berkurangnya komposisi spesies.

Beberapa penelitian yang
berhubungan dengan ekosistem
mangrove di Kecamatan Wori
sebelumnya telah dilakukan oleh Tidore
dkk., (2019), Takarendehang dkk.,
(2018). Penelitian struktur komunitas
dan zonasi mangrove di Desa Darunu
ini diharapkan agar dapat memberikan
informasi tentang pentingnya
keanekaragaman ekosistem mangrove
kepada masyarakat dan menjadi data
dasar dalam mengambil kebijakan


terkait dengan pengelolaan ekosistem mangrove di Desa Darunu.

\section{METODE PENELITIAN}

\section{Waktu dan Lokasi Penelitian}

Penelitian ini dilaksanakan selama 6 (enam) bulan di akhir tahun 2019 dan berlokasi di kawasan hutan mangrove Desa Darunu, Kecamatan Wori, Kabupaten Minahasa Utara, (Gambar 1).

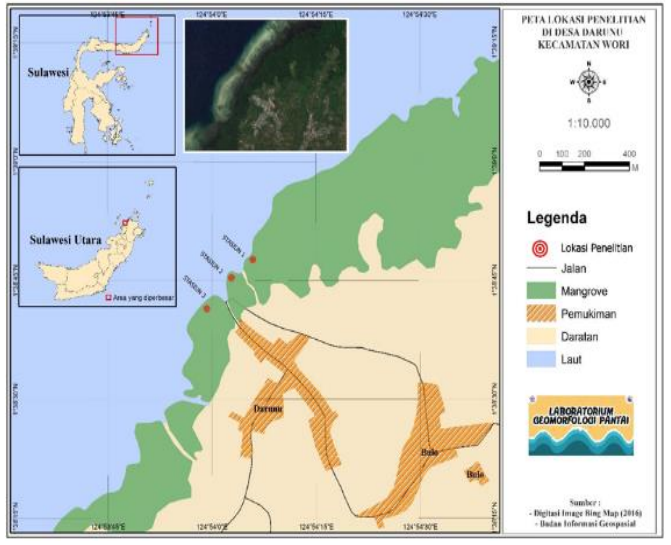

Gambar 1. Lokasi Penelitian (Desa Daurnu)

\section{Bahan dan metode}

Pengambilan data GPS (Global Positioning System) untuk penetapan koordinat lokasi. Tali arafia untuk garis transek dan dokumentasi spesies menggunakan kamera. Selanjutnya identifikasi mangrove menggunakan buku taksonomi mangrove yang baku. Data keberadaan zonasi mangrove dengan cara survei lapangan melihat jenis-jenis mangrove berdasarkan zonanya yang berada sepanjang garis transek.

Teknik pengambilan data yaitu dengan pencatatan semua jenis mangrove dalam lintasan transek garis (line transect), dan dalam petakan kuadran. Tehnik ini dilakukan dengan cara menarik garis lurus dari arah laut bagian vegetasi mangrove terluar ke arah darat di sepanjang bentangan atau hamparan hutan mangrove sampai di batas tumbuhan/hutan daratan (terrestrial vegetation). Bentangan transek garis sepanjang $100 \mathrm{~m}$ diletakkan di 3 stasiun dimana tiap stasiun hanya ada 1 transek garis dengan masing-masing ada 5 plot atau petak kuadran berukuran $10 \times 10 \mathrm{~m}^{2}$ dengan jarak antar plot sekitar 12,5 m (English 1994).

Pengambilan data struktur komunitas mangrove yang berada dalam plot diawali dengan melakukan identifikasi dan dokumentasi fotografi jenis mangrove, selanjutnya pengukuran diameter $(>4 \mathrm{~cm})$ batang pohon mangrove setinggi dada atau sekitar 1,3.

\section{Analisis Data}

Analisis data mengacu pada formula-formula struktur komunitas dalam Bengen (2003) yaitu:

\section{Kerapatan Jenis (Di)}

Di $=\frac{\text { Jumlah total individu ke- } \mathbf{i}}{\text { luas total area pengamatan }}$

\section{Kerapatan Relatif Jenis (RDi)}

$\mathbf{R D i}=\frac{\text { jumlah total individu ke-i }}{\text { total tegakan seluruh jenis }} \times \mathbf{1 0 0}$

\section{Frekuensi Jenis (Fi)}

$\mathbf{F i}=\frac{\text { jumlah petak ditemukan suatu jenis }}{\text { jumlah total petak yang dibuat }}$

Frekuensi Relatif Jenis (RCi)

$\mathbf{R f i}=\frac{\text { jumlah jenis ke-i }}{\text { jumlah total petak yang dibuat }} \times \mathbf{1 0 0}$

\section{Tutupan Jenis (Ci)}

$$
\mathbf{C i}=\frac{\text { jumlah besar area DBH jenis }-\mathrm{i}}{\text { Luas total area pengambilan contoh }}
$$

\section{Tutupan Relatif Jenis (RCi)}

$\mathbf{R C} \mathbf{i}=\frac{\text { tutupan relatif jenis ke }-\mathbf{i}}{\text { tutupan total untuk seluruh jenis }} \times \mathbf{1 0 0}$ 
Indeks Nilai Penting (INP)

INP=RDi+RFi+RCi Indeks Keanekaragaman Jenis $\left(\mathrm{H}^{\prime}\right)$

Keterangan :

$$
H^{\prime}=-\sum_{i=1}^{s} P i \operatorname{In} P i
$$

$\mathrm{H}^{\prime}$ : Indeks keanekaragan

$\mathrm{N}$ : Jumlah individu dalam komunitas $\left(\sum \mathrm{ni}\right)$

ni : Jumlah individu spesies atau jenis ke-i

$\mathrm{Pi}$ : Proporsi individu spesies ke-i (ni/N)

i : $1,2,3, \ldots . . s$

$\mathrm{s}:$ Jumlah genera

\section{Indeks Kemertaan Jenis (E)}

$\mathbf{E}=\frac{\text { Indeks keanekaragaman }}{\text { Jumlah jenis }}$

\section{HASIL DAN PEMBAHASAN}

\section{Jenis-Jenis Mangrove}

Ditemukan 5 jenis mangrove pada hutan mangrove di lokasi studi yaitu Sonneratia alba, Rhizophora apiculata, Rhizophora mucronata, Bruguiera gymnorrhiza, Avicennia officinalis dari 3 famili yaitu family Rhizophoraceae, Sonneratiaceae dan Avicenniaceae. Dari 5 jenis yang ditemukan, jenis Rhizophora apiculata yang paling umum ditemukan. Sesuai Kustanti (2011), bahwa R.apiculata merupakan salah satu jenis tumbuhan mangrove yang paling sering ditemukan dalam suatu kawasan hutan mangrove karena kemampuan beradaptasi yang baik terhadap lingkungannya jika dibandingkan dengan jenis lain.

\section{Struktur Komunitas Mangrove}

\section{Kerapatan Jenis dan Kerapatan Relatif Jenis}

Nilai kerapatan jenis tertinggi pada Stasiun 1 dimiliki oleh R.apiculata sebesar $0,06 \mathrm{ind} / \mathrm{m}^{2}$ dan terendah terdapat pada R.mucronata 0,01 ind $/ \mathrm{m}^{2}$. Sedangkan untuk nilai kerapatan relatif jenis yaitu $56.14 \%$, dan $7.02 \%$. Pada Stasiun 2 nilai kerapatan jenis tertinggi $R$.apiculata yaitu 0,05 ind $/ \mathrm{m}^{2}$ dan nilai terendah dimiliki oleh A.officinalis $0,01 \mathrm{ind} / \mathrm{m}^{2}$. Untuk nilai kerapatan relatif jenis $55,10 \%$ dan 12,24 . Selanjutnya untuk Stasiun 3 nilai kerapatan jenis tertinggi $R$.apiculata yaitu $0,05 \mathrm{ind} / \mathrm{m}^{2}$ dan nilai terendah dimiliki oleh B.gymnorrhiza 0,01 ind $/ \mathrm{m}^{2}$. Sedangkan untuk nilai kerapatan relatif jenis $51,06 \%$ dan $8,51 \%$ (Gambar 2 dan 3). Menurut Fachrul (2007). Nilai kerapatan menunjukan pola penyesuaian suatu jenis dengan lingkungannya, jenis dengan nilai kerapatan tertinggi memiliki pola penyesuaian yang besar.

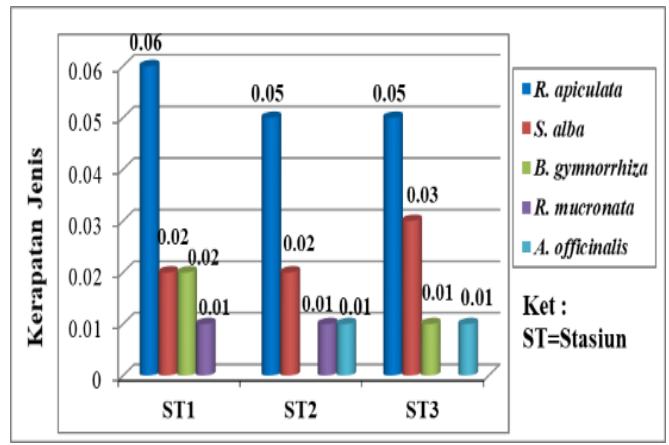

Gambar 2. Kerapatan Jenis Stasiun 1, 2 dan 3

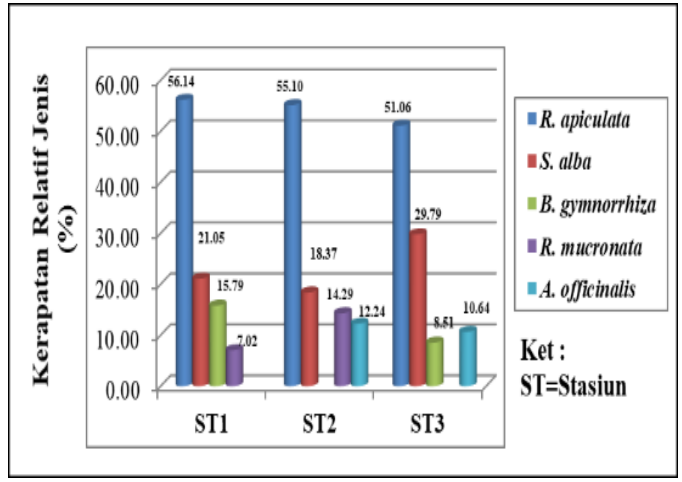

Gambar 3. Kerapatan Relatif Jenis Stasiun 1, 2 dan 3

Hasil analisis menunjukan bahwa nilai kerapatan jenis dan kerapatan relatif jenis tertinggi dimiliki oleh R.apiculata. Jenis ini memiliki penyebaran yang banyak di setiap transek dan plot ditemukan baik itu 
transek 1, 2 dan 3. Menurut Kusmana (2010) tingginya nilai kerapatan relatif dari jenis R.apiculata dikarenakan mangrove dari jenis Rhizophora sp. memiliki kawasan yang luas untuk hidup sehingga mampu berkembang dengan baik sampai ke daerah pedalaman selama masih mendapatkan suplai air laut dengan baik.

\section{Frekuensi Jenis dan Frekuensi Relatif Jenis}

Nilai tertinggi frekuensi jenis pada Stasiun 1 terdapat pada R.apiculata yaitu 1,00 sedangkan nilai terendah dimiliki oleh R.mucronata yaitu 0,40 untuk nilai frekuensi relatif jenis yaitu $33,22 \%$, dan 13,33\%. Pada Stasiun 2 nilai frekuensi jenis tertinggi dimiliki oleh $R$.apiculata yaitu 1.00 sedangkan terendah dimiliki oleh A.officinalis yaitu 0,40 . Untuk nilai frekuensi relatif jenis $35,71 \%$, dan $14,29 \%$. Stasiun 3 nilai frekuensi jenis tertinggi yaitu S.alba 1,00 sedangkan yang terendah dimiliki oleh B.gymnorrhiza dan A.officinalis yaitu 0,40 sedangkan untuk nilai frekuensi relatif jenis $35,71 \%$ dan $14,29 \%$. Frekuensi jenis tertinggi masih dimiliki $R$.apiculata pada setiap stasiun (Gambar 4 dan 5).

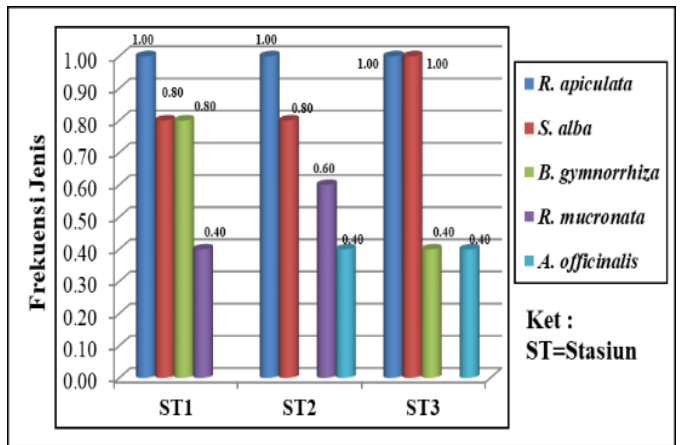

Gambar 4. Frekuensi Jenis Stasiun 1, 2 dan 3

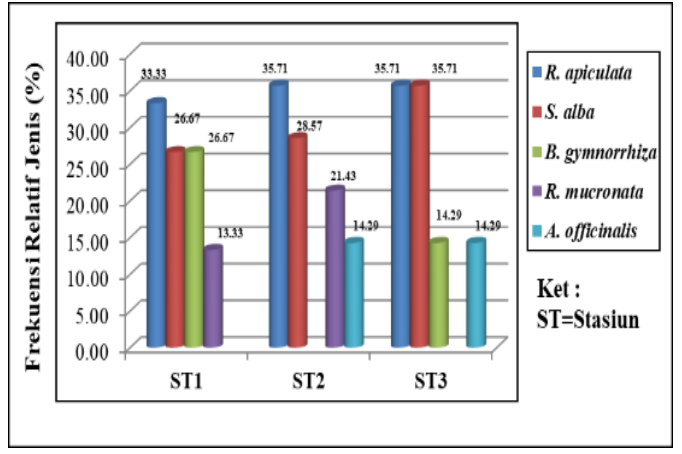

Gambar 5. Frekuensi Jenis Stasiun 1,2 dan 3

\section{Tutupan Jenis dan Tutupan Relatif Jenis}

Nilai tutupan jenis tertinggi pada Stasiun 1 dimiliki oleh S.alba yaitu 20,01 sedangkan nilai terendah dimiliki $R$. mucronata 0,61 . Untuk nilai tutupan relatif jenis $70,35 \%$ dan $2,16 \%$. Untuk Stasiun 2 nilai tutupan jenis tertinggi dimiliki oleh S.alba yaitu 45,02. Sedangkan nilai terendah terdapat pada R.mucronata yaitu 1,64. Untuk nilai tutupan relatif jenis $82,26 \%$ dan $2,99 \%$. Selanjutnya Stasiun 3 nilai tutupan jenis tertinggi dimiliki oleh S.alba yaitu 8,60 sedangkan yang terendah terdapat pada A.officinalis yaitu dengan nilai 1,90. Untuk nilai tutupan relatif jenisnya $50,37 \%$, dan $11,11 \%$ dapat dillihat pada (Gambar 6 dan 7). Faktor penting yang mempengaruhi nilai tutupan jenis ialah lingkaran batang pohon dan basal area dalam suatu lokasi pengambilan data (Jacobs dkk., 2019).

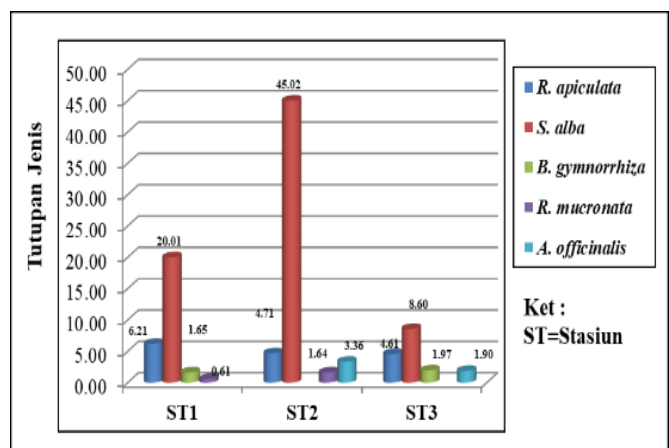

Gambar 6. Tutupan Jenis Stasiun 1, 2 dan 3 


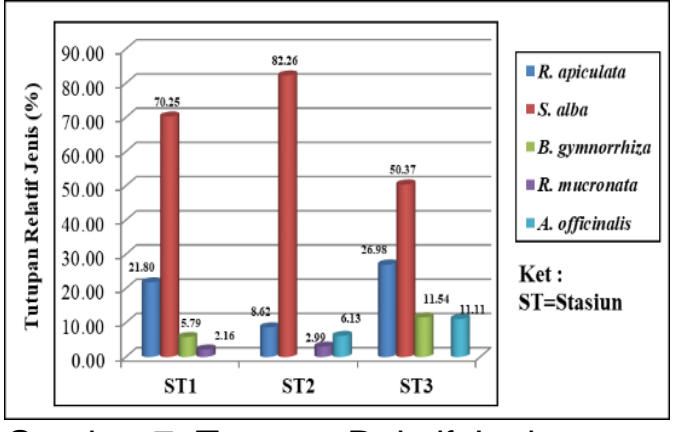

Gambar 7. Tutupan Relatif Jenis

Stasiun 1, 2 dan 3

\section{Indeks Nilai Penting}

Indeks Nilai Penting (INP) sebagai salah satu indeks yang digunakan untuk menghitung berdasarkan jumlah yang didapatkan dengan menentukan tingkat dominasi jenis dalam suatu komunitas tumbuhan yang mendominan akan memiliki INP (Indriyanto, 2006 dalam Kordi, 2012).

Untuk indeks nilai penting tertinggi pada Stasiun 1 terdapat pada S.alba yaitu 111,97 . Sedangkan nilai terendah dimiliki oleh R.mucronata 22,51. Pada Stasiun 2 indeks nilai penting tertinggi dimiliki S.alba yaitu 129,20 dan nilai terendah terdapat pada A.officinalis 32,67 . Selanjutnya Stasiun 3 indeks nilai penting tertinggi dimiliki oleh jenis S.alba 115,87 sedangkan nilai terendah terdapat pada R.mucronata yaitu 34,33 (Gambar 8).

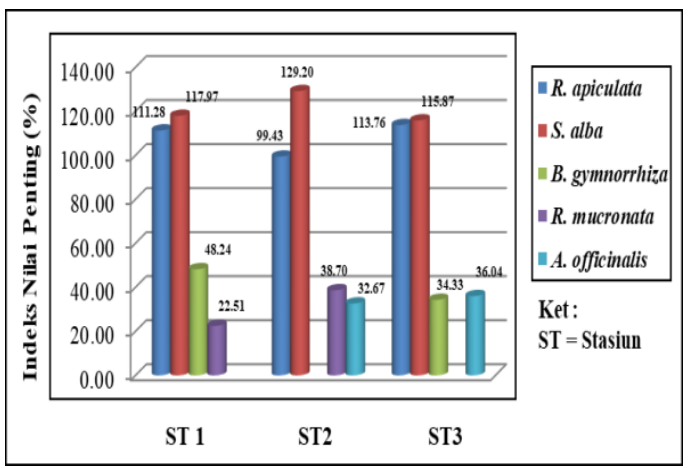

Gambar 8. Indeks Nilai Penting Stasiun 1,2 dan 3

Berdasarkan pada hasil INP di Gambar 10 jika suatu jenis menunjukkan nilai penting yang tinggi maka peranan jenis tersebut sangat besar terhadap jenis lainnya dalam ekosistem mangrove. Bengen (2004) dalam Sasauw (2016) menyatakan bahwa INP berkisar antara 0-300 menunjukan keterwakilan jenis mangrove yang berperan dalam ekosistem mangrove berarti suatu jenis mangrove memiliki peran dan pengaruh yang penting dalam komunitas.

\section{Indeks Keanekaragaman dan Indeks Kemerataan Jenis}

Nilai indeks keanekaragaman tertinggi terdapat pada stasiun 2 yaitu 1,17 . Sedangkan yang terendah dimiliki oleh Stasiun 1 yaitu 1,14. Pada stasiun 2 menunjukkan bahwa komunitas tersebut memiliki kompleksitas dengan interaksi spesies yang terjadi di dalam komunitas cukup baik. Sedangkan rendahnya nilai Keanekaragaman pada stasiun 2 disebabkan pertumbuhan mangrove tidak stabil mungkin karena terdapat jenis yang telah mati. Rendahnya keanekaragaman di desa ini sebabkan oleh faktor fisika kimia. Untuk nilai kemerataan jenis nilai nilai tertinggi dimiliki oleh stasiun 1 yaitu 5,48 . Sedangkan untuk nilai kemerataan jenis terendah terdapat pada Stasiun 2 yaitu 5,46 (Gambar 9 dan 10). Menurut Indriyanto (2006) suatu komunitas dikatakan memiliki keanekaragaman spesies yang tinggi jika komunitas itu disusun oleh banyak spesies.

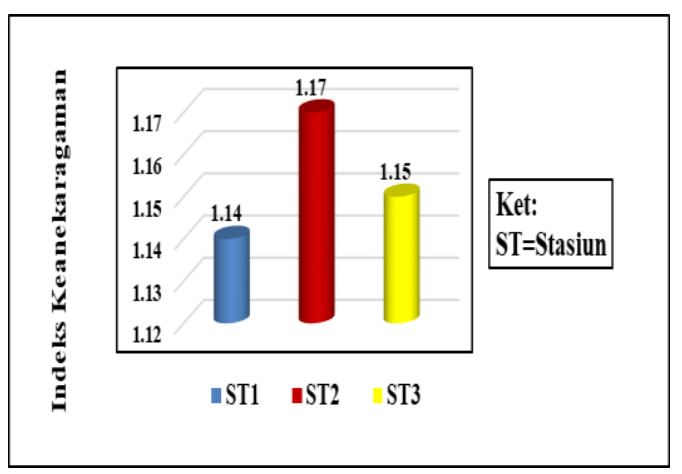

Gambar 9. Indeks Keanekaragaman stasiun 1, 2 dan 3 


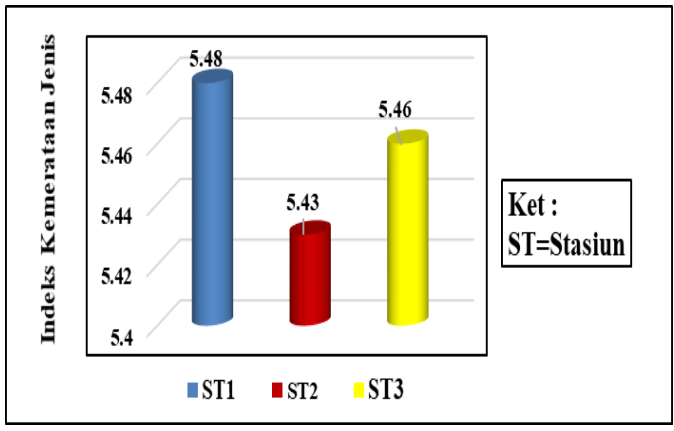

Gambar 10. Indeks Kemerataan Jenis Stasiun 1, 2 dan 3

\section{Zonasi Vegetasi Mangrove}

Zonasi merupakan kumpulan vegetasi mangrove yang saling berdekatan mempunyai sifat atau tidak ada yang sama sekali jenis walaupun tumbuh dalam lingkungan yang sama dimana dapat terjadi perubahan lingkungan.

\section{Stasiun Satu}

Zona ini ditumbuhi oleh S.alba dan R.apiculata dengan lumpur berpasir, selanjutnya di zona tengah masih di tumbuhi oleh $R$.apiculata yang berasosiasi dengan B.gymnorrhiza dan R.mucronata dengan substrat lumpur. Tapi jenis terbanyak diwakili oleh R.apiculata dan paling belakang ditemukan Nypa.

Stasiun 1
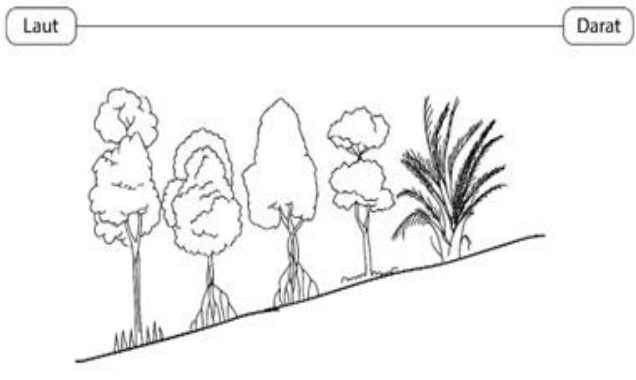

Gambar 11. Zonasi vegetasi mangrove

\section{Stasiun Dua}

Zona di depan ditumbuhi oleh $S$.alba dan $R$.apiculata dengan substrat lumpur berpasir, zona selanjutnya masih di tumbuhi oleh $R$.apiculata yang berasosiasi dengan R.mucronata dan A.offiinalis dengan substrat lumpur berpasir dan lumpur, di belakang mendekati hutan daratan tetap mendominasi R.apiculata dengan substrat lumpur.

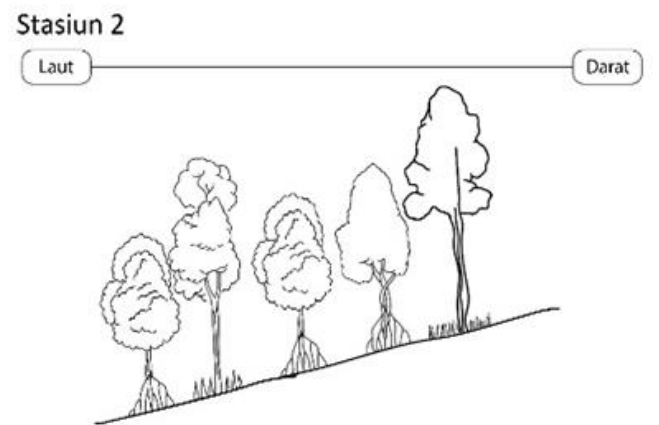

Gambar 12. Zonasi vegetasi mangrove

\section{Stasiun Tiga}

Zona depan ditumbuhi oleh dan $R$.apiculata dan S.alba dengan substrat lumpur berpasir, zona berikutnya masih ditumbuhi oleh R.apiculata yang berasosiasi dengan jenis B.gymnorrhiza dan A.officinalis dengan substrat lumpur berpasir dan lumpur, dibelakang mendekati hutan darat masih R.apiculata dengan substrat lumpur.
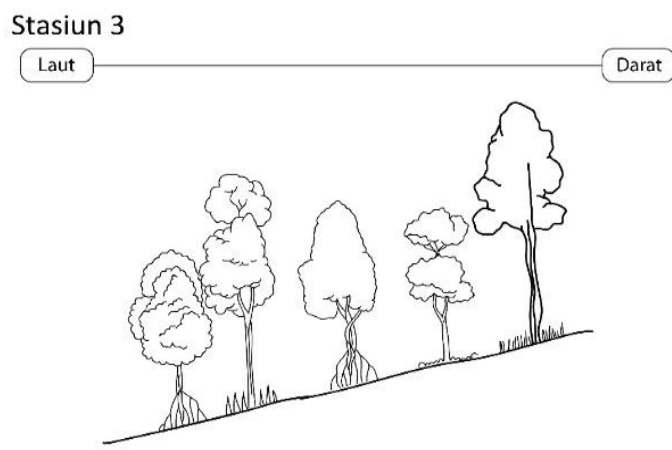

Gambar 13. Zonasi vegetasi mangrove

Hal ini menunjukan bahwa tidak semua mangrove tumbuh dengan zonasi yang sama. tetapi tergantung oleh jenis dan kondisi lapangan. (Chapman, 1977 dalam Mughofa dkk., 
2018). Hal ini dapat mengindikasikan bahwa pertumbuhan mangrove jenis R.apiculata tidak dipengaruhi oleh letaknya zona, melainkan lebih dipengaruhi oleh jenis substrat yang mengandung lumpur. Menurut Bengen (2002) dalam Mughofa dkk., (2018). mengatakan bahwa zonasi tengah sangat cenderung didominasi oleh Rhizophora spp dan Bruguiera spp. Untuk zona terbuka yang berhadapan dengan laut akan didominasi oleh jenis Sonneratia.

\section{KESIMPULAN}

Struktur komunitas mangrove di Desa Darunu, ditemukan 5 jenis mangrove yaitu: Rhizophora apiculata, Sonneratia alba, Bruguiera gymnorrhiza, Rhizophora apiculata dan Avicennia Officinalis dan R.apiculata merupakan jenis yang ditemukan di semua titik pengamatan

Zonasi vegetasi mangrove menunjukan bahwa pada Stasiun 1 zona bagian depan ditumbuhi oleh $S$. alba dengan substrat lumpur berpasir. Sedangkan untuk Stasiun 2 dan 3 zona paling depan ditumbuhi oleh R.apiculata dengan substrat lumpur berpasir dan lumpur. Secara umum lokasi ini terdapat lumpur berpasir dan lumpur.

\section{DAFTAR PUSTAKA}

Bengen, D. G. 2003. Pengenalan Dan Pengelolaan Ekosistem Mangrove. Pusat Kajian Sumber Daya Pesisir Dan Lautan. Institut Pertanian Bogor, Bogor.

Cahyanto, I. dan Kuraesin, R. 2013. Struktur Vegetasi Mangrove Di Pantai Muara Marunda Kota Administrasi Jakarta Utara. Jurusan Biologi Fakultas Sains Dan Teknologi. Universitas Islam Negeri Sunan Gunung Djati Bandung. Volume VII. No. 2. ISSN 1979-8911. Hal. 73-76.
English, S. C. Wilkinson, V. Baker. Survey Manual For Tropical Marine Resources. ASEANAustralia Marine Science Project: Living Coastal Resources.Australian Institute Of Marine Science. Townsville, Australia.

Fachrul, M.F. 2007. Metode Sampling Bioekologi. Jakarta: Bumi Aksara. Indriyanto, 2006. Ekologi Hutan. Jakarta: Bumi aksara.

Jacobs, R. Kusen, J. D. Sondak, C. F. A. Boneka, F. B. Warouw, V. Mingkid, W. M. 2019. Struktur Komunitas Ekosistem Mangrove Dan Kepiting Bakau Di Desa Lamanggo Dan Desa Tope, Kecamatan Biaro, Kabupaten Kepulauan Siau, Tagulandang, Biaro. Program Studi IImu Kelautan Fakultas Perikanan dan IImu Kelautan, Universitas Sam Ratulangi, Manado. Junal Pesisir dan Laut Tropis. Vol. 1. No. 1.

Kordi, K. M. G. H. 2012. Ekosistem Mangrove : Potensi Fungsi dan Pengelolaannya. Jakarta : Rinek. Cipta.

Kusen, J. D., Lumingas, L. J L \& Rondo, M. 2016. Ekologi Laut Tropis. Fakultas Perikanan dan Ilmu Kelautan. Universitas Sam Ratulangi Manado.

Kusmana, C. 2005. Rencana Rehabilitasi Hutan Mangrove dan Hutan Pantai Pasca Tsunami di NAD dan Nias. Makalah Dalam Lokakarya Hutan Mangrove Pasca Tsunami. Medan.

Kustanti, A. 2011. Evolusi Hak Kepemilikan Dan Penataan Peran Para Pihak Pada Pengelolaan Ekosistem Hutan Mangrove Dengan Kemunculan Tanah Timbul. Disertasi. Program 
Pascasarjana IImu Pengelolaan Hutan. IPB. Bogor.

Mughofar, A. Masykuri, M dan Setyono, P. 2018. Zonasi Dan Komposisi Vegetasi Hutan Mangrove Pantai Cengkrong Desa Karanggandu Kabupaten Trenggalek Provinsi Jawa Timur. Program Studi Pendidikan Kimia, Fakultas Keguruan dan IImu Pendidikan, Universitas Sebelas Maret Jurnal Pengelolaan Sumberdaya Alam dan Lingkungan Vol. 8 No. 1. Hal 77-82.

Retna, P.P. Pribadi, R. Zainuri, M. dan Angraini, M. 2016. Struktur Komunitas Mangrove Di Desa Mojo Kabupaten Pemalang Jawa Tengah. Program Studi IImu Kelautan Fakultas Pertanian Universitas Bengkulu. Jurusan IImu Kelautan Fakultas Perikanan dan IImu Kelautan Universitas Diponegoro. Jurnal Enggano. Vol. No. 1. ISSN: 2527-5186. 10 hal.

Sasauw, J., Kusen, J.D dan Schaduw, W. N. J. 2016. Struktur Komunitas Mangrove Di Kelurahan Tongkaina Manado. Program Studi IImu Kelautan, Fakultas Perikanan dan IImu Kelautan. Universitas Sam Ratulangi Manado. Jurnal Pesisir dan Laut Tropis. Vol. 2 No. 1. 22 hal.

Schaduw, J.N.W. 2016. Kondisi ekologi mangrove Pulau Bunaken Kota Manado Provinsi Sulawesi Utara. Fakultas Perikanan Dan IImu Kelautan. Universitas Sam Ratulangi. Jurnal LPPM Bidang Sains Dan Teknologi. Volume 3. Nomor 2. Hal. 64-74

Takarendehang, R. Sondak, C. F.A. Kaligis, E. Kumampung, D. Manembu, I. S. Unstain N.W.J. Rembet Kondisi Ekologi Dan Nilai
Manfaat Hutan Mangrove Di Desa Lansa, Kecamatan Wori, Kabupaten Minahasa Utara. Program Studi IImu Kelautan Fakultas Perikanan dan IImu Kelautan, Universitas Sam Ratulangi, Manado. Jurnal Pesisir dan Laut Tropis Vol. 6. No. 2.

Tidore, F. Rumengan, A. Sondak, C. F.A. Mangindaan, R. E.P. Runtuwene, H.C.C. Pratasik, S. B. 2018. Estimasi Kandungan Karbon (C) Pada Serasah Daun Mangrove Di Desa Lansa, Kecamatan Wori, Kabupaten Minahasa Utara. Program Studi Ilmu Kelautan Fakultas Perikanan dan IImu Kelautan, Universitas Sam Ratulangi, Manado. Jurnal Pesisir dan Laut Tropis Vol. 2. No. 1.

Wantasen, A. S. 2013. Kondisi Kualitas Perairan Dan Substrat Dasar Sebagai Faktor Pendukung Aktivitas Pertumbuhan Mangrove Di Pesisir Desa Basaan 1 Kabupaten Minahasa Tenggara. Jurnal IImiah Platx Vol. 1 No. 4 ISSN 2302-3589. Hal 205-207. 